\title{
Technology Aspects of E-Government Readiness in Developing Countries: A Review of the Literature
}

\author{
Mustafa Omar M. Baeuo ${ }^{1}$, Nor Zairah Binti Ab. Rahim ${ }^{1} \&$ Asma Ali Mosa Alaraibi ${ }^{1}$ \\ ${ }^{1}$ Advanced Informatics School, Universiti Teknologi Malaysia (UTM), Malaysia \\ Correspondence: Mustafa Omar M. Baeuo, Advanced Informatics School, Universiti Teknologi Malaysia (UTM), \\ Kuala Lumpur, Malaysia. Tel: 60-126-441-426. E-mail: mustafaomar12@yahoo.co.nz
}

Received: July 25, 2016

Accepted: August 23, $2016 \quad$ Online Published: September 22, 2016

doi:10.5539/cis.v9n4p1

URL: http://dx.doi.org/10.5539/cis.v9n4p1

\begin{abstract}
The rapid global growth of the Internet and information technology has inspired many governments to transform their traditional services into electronic ones. Many governments are now developing, implementing and improving their strategies to transform government services using information and communication technologies (ICTs). E-Government, as it is known, has become a popular focus of government efforts in many developed countries and, more recently, in several developing countries. Further, e-government services have become a significant and active means for interaction among government, citizens and businesses. E-government comprises several dimensions, one of the main ones being e-government readiness. To put technology to effective use, a government must be "ready". E-government readiness helps a government to measure its stages of readiness, identify its gaps, and then redesign its government strategy. One of the aspects of e- government readiness is that of technological readiness, which plays an important role in implementing an effective and efficient e- government project. This paper explores the gaps in current knowledge relating to the technological aspects of e-government readiness through the conduct of a literature review. In particular, the review focuses on the models and frameworks that have been developed to assess e-government readiness.
\end{abstract}

Keywords: e-government readiness, technological aspects, assessment, developing countries

\section{Introduction}

Government services are provided through a variety of channels such as banks, post offices and so on. In these situations, technology plays a key role in the services in order to improve government infrastructure. E-government, or the use of technology in government services, has become a global issue having a significant influence upon all public sectors and economies; hence, there is a need for global cooperation as well as knowledge and experience exchange in the area. Currently, all countries are seeking to meet user expectations, but few of them have the knowledge required for these expectations. Encouraging citizens to participate in the public sector development has created an unprecedented recognition among governments of the whole public-sector need to deliver services in a different way (OECD, 2008). E-Government adoption requires a high level of satisfaction from both citizens and businesses. A high satisfaction level will succeed in increasing the e-government adoption rate. It will also ensure transparency in government operations and restore trust in governments (Othman \& Razali, 2013). However, the adoption of e-government needs significant requirements to be met, such as that of technological readiness.

Having introduced the concept of e-government in Section 1, the remainder of this paper is structured as follows: Section 2 presents the definition of e-government; Section 3 discusses the barriers to and challenges for e-government adoption; Section 4 indicates the degree of e-government readiness; Section 5 discusses technology readiness aspects of e-government; Section 6 presents technological aspects relating to e-government readiness and the gap; while Section 7 presents the conclusion and future directions for our work.

\section{E-Government Definition}

In recent years, the revolution of Information Communication Technology (ICT) has changed the way in which governments around the world interact with their citizens, businesses, government agencies and employees (Joseph, 2014). In other words, in the current information age, the basic principles of government services changes markedly. All countries now seek to deliver their services through ICT facilitation. In this regard, and 
according to Joseph (2014), the phenomenon of electronic government (henceforth called e-government) is derived from the desire for efficient service delivery. E-government services have become a significant and active means for interaction among government, citizens and businesses. However, there is as yet no commonly accepted definition (Solli, 2010), despite many definitions existing in literature. Some of them focus only on using ICT (especially the Internet) to deliver high quality government services. Other definitions view e-government as a wide and all-encompassing effort for transforming government and governance (Grant \& Chau, 2006). Following is a list of some of the e-government definitions:

- E-government refers to "government systems of ICT to transform relations with citizens, the private sector and other government agencies in order to enhance empowerment of citizens, government efficiency and delivery of service, increased transparency and accountability" (Karokola, Kowalski, \& Yngstrom, 2013).

- The World Bank defined e-government as "government agencies' use of ICT, such as mobile computing and Internet, which have the capability to change relations with citizens, businesses, and other government arms" (Othman \& Razali, 2013; Mollah, Islam, \& Islam, 2012; Alghamdi, Goodwin, \& Rampersad, 2011).

- According to Mollah et al. (2012), and UNESCO defined e-government as "the public sector's use of ICT to improve delivery of information and service, encourage participation of citizens in the decision-making process and provide increased transparency and effectiveness of government".

- The common definition of e-government means "use of ICTs to enhance government business related to the provision or enhancement of public services or the management of internal operations of government" (Novakouski \& Lewis, 2012).

- According to Almarabeh and AbuAli (2010) most researchers agreed that electronic government denotes government use of ICT to interact with various stake holders and to conduct business with government agencies by use of the Internet and other various electronic media.

- E-government refers to the capability of various government agencies to provide government information and services at any time to citizens using electronic means speedily and properly, resulting in less costs and effort via a single Internet site (Odat, 2012).

- Zhang and Hou (2011) defined e-government as "the information technology use (particularly the Internet) by government to enhance operations of government, enhance citizens' participation, and provide services".

All of the above definitions indicate that e-government refers to the information and services delivery by governments via the Internet or other digital media to various stakeholders. The definitions also refer to the technological capability for improving various sectors of government; thereby transforming the relations between governments and various stakeholders. Further, this results in an increase in their interaction in such a manner as to significantly improve the lives of their citizens.

Using ICT to facilitate interaction between government and other stakeholders has been manifested in four e-government types, specifically: Government-to-citizen (G2C); government-to-business (G2B); government-to-employee (G2E) and government-to-government (G2G) (Gant, 2008; Qaisar \& Khan, 2010; Jouzbarkand et al., 2011; Odat, 2012; Fgee \& Alkallas, 2013). Governments should seek to enhance these interactions so as to simplify and improve all democratic aspects of government related to citizens and businesses alike.

In summary, it can be perceived that the most important feature which has been shown in the definition of e-government is the use and implementation of ICT in government services. In general, e-government refers to the concept of performing activities related to government matters through the use of ICT. In this regard, it refers to the concept of very new and innovative approaches by which to solve a country's problem and issues. However, the e-government concept is something more than utilizing ICT and Internet merely for information access; rather, it is about transforming the fundamental relationship between government and the people.

\section{E-Government Barriers and Challenges}

Most electronic government projects in developing countries have failed due to the gap existing between e-government systems design and reality. Many developing countries simply implement e-government systems designs from developed countries without taking into consideration the differences in historical and cultural aspects, infrastructure, people, as well as economic and government structures (Mkude \& Wimmer, 2013).

Designing and sustaining e-government systems requires rigorous consideration of political, economic, technological, social, and cultural issues in addition to the legal status of the country. Such prerequisites impose significant design challenges, which have to be faced by developing countries. Most developing countries suffer 
from problems relating to emerging economies, high levels of corruption, political instabilities, unclear legal structures and diverse social and cultural norms, all of which greatly contribute to the challenges involved in designing e-government projects. According to Mkude and Wimmer (2013), the challenges involved in designing e-government systems in developing countries could be summarized as, specifically: political and organizational leadership; formulation of strategy and policy; prioritization of initiatives; availability of financial resources; public-private partnership; ICT literacy levels of public sector employees; ICT literacy levels of end users; formulation of legal framework; formulation of security and privacy guidelines; cultural factors; infrastructure issues; integration of backend processes; and finally, awareness of opportunities.

In order to provide practical experiences and to facilitate successful e-government adoption in developing countries, governments should encourage more and varied publications relating to experiences illustrating frameworks, challenges faced, failures, risks and proposed remedies. Such collaboration will result in reduction of failures, encourage application of innovative solutions among governments and enhance empirical learning (Mkude \& Wimmer, 2013).

The governments of developing countries confront significant constraints in building e-Government services. These constraints completely shape the difference in adoption levels and e-Government usage in developed countries (Gant, 2008). Almarabeh and AbuAli (2010) summarized the expected challenges that face e-government program implementation during development of successful e-government as follows:

- Development of Infrastructure: It is essential for those states using electronic government practices to have the necessary infrastructure to be able to benefit from modern technologies. However, many developing countries lack the required infrastructure for prompt implementation of e-government services.

- Law and Public Policy: Use of ICT by government could result in policy or legal barriers. Legislative assemblies must guarantee the update of laws related to e-documents and transactions.

- Digital Divide: This refers to the gap between individuals who have access to the Internet and those who lack access. Those who lack access do not have the opportunity to learn basic computer literacy skills and cannot access information that could produce improved economic prospects. Thus, they cannot take advantage of electronic government services.

- $\quad$-Literacy Accessibility: E-Literacy accessibility highlights the plight of marginalized groups who cannot benefit from ICT because they lack computer abilities and skills. E-government has the capability to balance access to government services or increase the difficulty for users.

- Accessibility: Governments must provide services to all people regardless of their physical capabilities (impediments posed by blindness, deafness, etc.). Therefore, it is essential that e-services be designed with proper interfaces.

- Trust: To ensure success, e-government must build trust with and between government agencies, as well as with business and citizens.

- Privacy: Governments gather huge amounts of data on their citizens every day; therefore, they have a duty of care to protect the personal information they hold. It is a vital and significant issue to protect the confidentiality of the personal information stored in the government database while at the same time facilitating and enhancing their use.

- Security: In spite of the costs involved, security should be considered in the design phase because its violation may damage the trust of people in e-government. Trust is a fundamentally imperative part of e-government. Lack of trust could push some individuals who may be cautious about the use of technology to hesitate or avoid using online services that request personal information.

- Transparency: It is difficult for citizens to see and understand how decisions of government are made. Transparency absence hinders people from effective sharing in government and from protesting against inequitable decisions. A transparency absence can also hide official favoritism and graft.

- Interoperability: Putting incongruent record formats online will not be streamlined nor will it decrease the workload forced on individuals and government authorities. Dependable e-government has an obligation for thorough redesign of legacy systems.

- Records Management: Good management of information can assist authorities to distinguish barriers to more effective government practices. A framework for information management is important by which to understand available data and to help policy makers conclude useful analysis rapidly enough to be able to respond to social and financial developments. 
- Permanent availability and Preservation: Governments consider that the historic documentation significance of ICT ensures quick and cheap data dissemination, in addition to ensuring compact and proper storage.

- Education and Marketing: E-services of government can be helpful if people have knowledge about them; thus, there is a need for education and awareness programs.

- Public/Private Competition/Collaboration: An important inquiry relates to the question of where government controls end and when the private sector assumes control in e-government endeavors.

- Workforce Issues: Human resources must be organized and trained in e-government objectives. A motivated and well-trained work force is basic to achievement of e-government objectives.

- Cost Structures: Governments should attempt to invest in suitable programs that can produce savings in spite of difficulties encountered in planning and budgeting in a changing environment.

- Benchmarking: Governments must conduct an orderly assessment of development and efficacy of their investments in e-government in order to determine if expressed objectives and targets are being met on schedule.

Based on these challenges, Odat (2012) developed a general framework concerning challenges and opportunities that confront e-government project implementation in developing countries. This is shown in Figure 1 following.

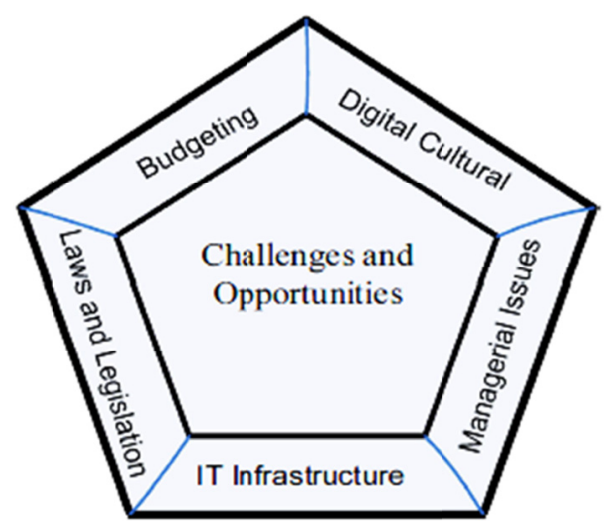

Figure 1. Challenges and Opportunities Framework (Odat, 2012)

The details concerning the challenges and opportunities framework are as follows:

\section{- $\quad$ IT Infrastructure}

This concerns a lack of technological skills among leaders, employees and citizens, as well as a paucity of hardware and software and knowledge as to their update or maintenance. In addition, there is a lack of communication systems, as well as a lack of digital information. This includes a scarcity of databases with different formats and capacity to archive various document types.

\section{- Managerial Issues}

Top management and administration should be in support of e-government programs. They also should have the competency to handle issues such as: workforce turnover and resistance to change; increased transparency in addition to collaboration and coordination among the e-government parties.

\section{- Digital Cultural}

This includes issues such as: digital divide; e-literacy; lack of awareness; trust; security and privacy.

\section{- Laws and Legislation}

Legislative assemblies must be able to guarantee that laws are upgraded to perceive e-documents and transactions. Although there has been a rapid advance in the development of systems and applications, there is at the same time an absence of legislations and laws that back the electronic systems.

\section{- Budgeting}

Any e-government project is a mega project that needs budgeting at all stages. However, developing countries are faced with problems such as: absence of funds; lack of availability of resources management; as well as 
widespread corruption and misuse of public money.

The barriers and challenges to e-government in developing countries are numerous and difficult and they relate to all organizational, technological, economic, social and legal aspects. It is not easy to overcome the effect of all these obstacles since great efforts are needed from both governments and citizens. ICT is considered as being a major challenge to the implementation of e-government in developing countries, but it offers significant opportunities for developing e-government practices. These remain limited because its potential benefits are not exploited effectively and efficiently in most of these countries. The e-government is the economic basis for organizational and political reformation and countries which have successfully developed e-government foundations have achieved excellent development outcomes.

The main objective of this part of the literature review was to identify barriers and challenges to e-government implementation. As mentioned above, there are some barriers and challenges to e-government readiness which have been reviewed and explained in this part of the study. A further and comprehensive review of the literature indicates that there are still more barriers and challenges existing than those mentioned above. There are many barriers that affect the success of e-government readiness. The researcher has summarized these in Table 1 follow

Table 1. Comparison between E-government Barriers and Challenges

\begin{tabular}{|c|c|c|c|c|c|c|c|c|c|c|c|c|c|c|c|c|c|c|c|}
\hline $\begin{array}{l}\text { Author/s } \\
\text { Barriers and } \\
\text { Challenges of } \\
\text { E-government }\end{array}$ & 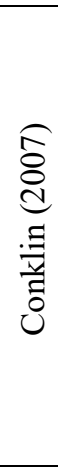 & 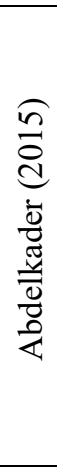 & 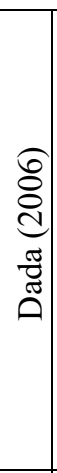 & 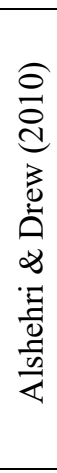 & 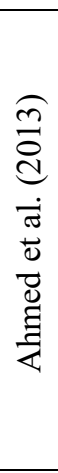 & 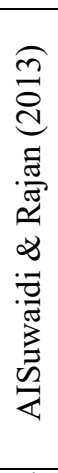 & 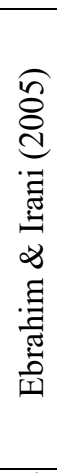 & 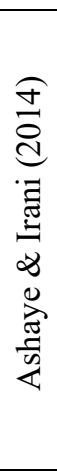 & 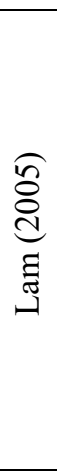 & 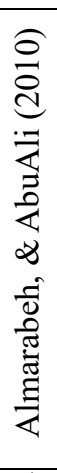 & 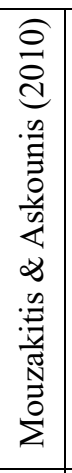 & $\begin{array}{l}\text { f্} \\
\text { d } \\
\text { d } \\
\text { z } \\
\text { z }\end{array}$ & 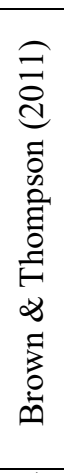 & 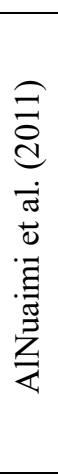 & 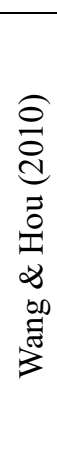 & 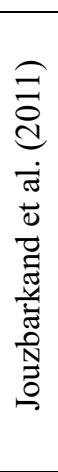 & 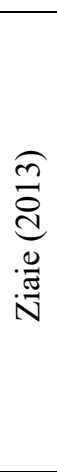 & 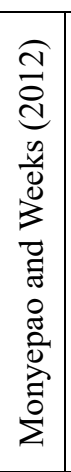 & 亚 \\
\hline Infrastructure & & & & & $\sqrt{ }$ & $\sqrt{ }$ & $\sqrt{ }$ & & & $\sqrt{ }$ & & $\sqrt{ }$ & $\sqrt{ }$ & $\sqrt{ }$ & $\sqrt{ }$ & & $\sqrt{ }$ & & 9 \\
\hline $\begin{array}{l}\text { Privacy and } \\
\text { security risk } \\
\text { barriers }\end{array}$ & & $\sqrt{ }$ & & $\sqrt{ }$ & & $\sqrt{ }$ & $\sqrt{ }$ & $\sqrt{ }$ & & $\sqrt{ }$ & & & & $\sqrt{ }$ & $\sqrt{ }$ & $\sqrt{ }$ & & & 9 \\
\hline $\begin{array}{l}\text { Legislative } \\
\text { Barriers }\end{array}$ & & $\sqrt{ }$ & & & & $\sqrt{ }$ & & $\sqrt{ }$ & $\sqrt{ }$ & & & $\sqrt{ }$ & $\sqrt{ }$ & & & & & & 6 \\
\hline $\begin{array}{l}\text { Administrative } \\
\text { Barriers }\end{array}$ & $\sqrt{ }$ & $\sqrt{ }$ & & $\sqrt{ }$ & & $\sqrt{ }$ & & & $\sqrt{ }$ & $\sqrt{ }$ & & $\sqrt{ }$ & & & & $\sqrt{ }$ & $\sqrt{ }$ & & 9 \\
\hline $\begin{array}{l}\text { Technological } \\
\text { Barriers }\end{array}$ & $\sqrt{ }$ & $\sqrt{ }$ & & $\sqrt{ }$ & $\sqrt{ }$ & & $\sqrt{ }$ & $\sqrt{ }$ & $\sqrt{ }$ & & & $\sqrt{ }$ & & & $\sqrt{ }$ & $\sqrt{ }$ & & $\sqrt{ }$ & 11 \\
\hline $\begin{array}{l}\text { Cultural } \\
\text { Barriers }\end{array}$ & & $\sqrt{ }$ & & & $\sqrt{ }$ & $\sqrt{ }$ & & & & $\sqrt{ }$ & & & & & & & & & 4 \\
\hline Resistance & & $\sqrt{ }$ & & & & & & & & & & & & & & $\sqrt{ }$ & & & 2 \\
\hline Hard-soft gap & & & $\sqrt{ }$ & & & & & & & & & & & & & & & & 1 \\
\hline $\begin{array}{l}\text { Private-public } \\
\text { gap }\end{array}$ & & & $\sqrt{ }$ & & & & & & & $\sqrt{ }$ & & & & & & & & & 2 \\
\hline $\begin{array}{l}\text { Country-conte } \\
\mathrm{xt}\end{array}$ & & & $\sqrt{ }$ & & & & & & & & & & & & & & & & 1 \\
\hline Collaboration & & & & $\sqrt{ }$ & & & $\sqrt{ }$ & & & $\sqrt{ }$ & & $\sqrt{ }$ & & & & & & & 4 \\
\hline $\begin{array}{l}\text { Lack of } \\
\text { Qualified } \\
\text { people }\end{array}$ & & & & $\sqrt{ }$ & & $\sqrt{ }$ & & $\sqrt{ }$ & & & $\sqrt{ }$ & & & $\sqrt{ }$ & & & & & 5 \\
\hline $\begin{array}{l}\text { Personnel and } \\
\text { Training }\end{array}$ & & & & $\sqrt{ }$ & & $\sqrt{ }$ & & $\sqrt{ }$ & & $\sqrt{ }$ & & & & & & & & & 4 \\
\hline $\begin{array}{l}\text { Social (Digital } \\
\text { Divide) }\end{array}$ & & & & $\sqrt{ }$ & $\sqrt{ }$ & & & & & $\sqrt{ }$ & & & $\sqrt{ }$ & $\sqrt{ }$ & $\sqrt{ }$ & & $\sqrt{1}$ & & 7 \\
\hline
\end{tabular}




\begin{tabular}{|c|c|c|c|c|c|c|c|c|c|c|c|c|c|c|c|c|c|c|c|}
\hline $\begin{array}{l}\text { Barriers and } \\
\text { Challenges of } \\
\text { E-government }\end{array}$ & 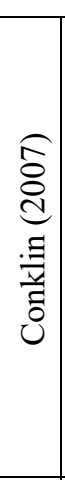 & 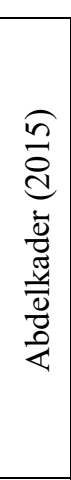 & 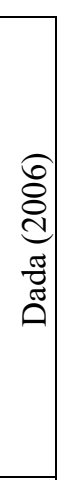 & 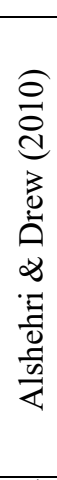 & 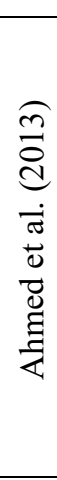 & 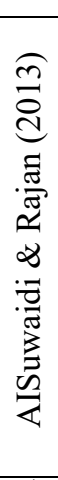 & 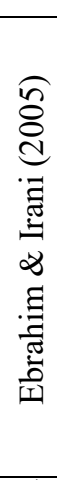 & 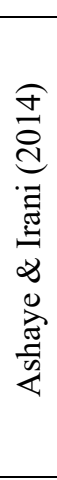 & 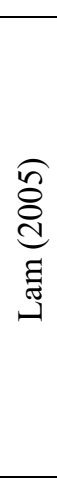 & 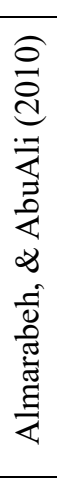 & 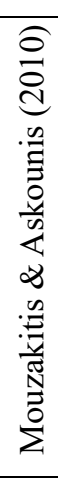 & $\begin{array}{l}\text { f } \\
\stackrel{d}{d} \\
\bar{z} \\
\frac{0}{z}\end{array}$ & 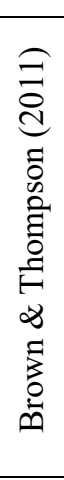 & 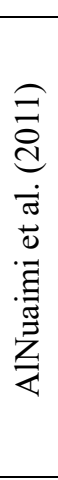 & 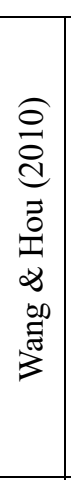 & 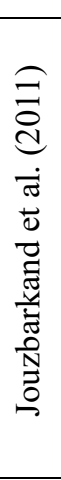 & 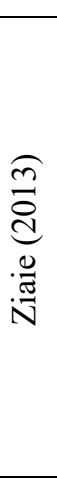 & 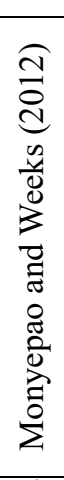 & 嗬 \\
\hline Financial & & & & $\sqrt{ }$ & & $\sqrt{ }$ & $\sqrt{ }$ & & & & & & & & & $\sqrt{ }$ & & $\sqrt{ }$ & 5 \\
\hline Organizational & & & & & $\sqrt{ }$ & $\sqrt{ }$ & & $\sqrt{ }$ & $\sqrt{ }$ & & & & & $\sqrt{ }$ & & & & & 5 \\
\hline Skills & & & & & & & $\sqrt{ }$ & & & $\sqrt{ }$ & $\sqrt{ }$ & & & & & & & & 3 \\
\hline $\begin{array}{c}\text { Lack of } \\
\text { awareness }\end{array}$ & & & & & & & & & & & & & & $\sqrt{ }$ & & & & & 1 \\
\hline $\begin{array}{c}\text { Lack of } \\
\text { Information }\end{array}$ & $\sqrt{ }$ & & & & & & & & & & $\sqrt{ }$ & & & & & $\sqrt{ }$ & & & 2 \\
\hline
\end{tabular}

Table 1 highlights the important fact that most of the barriers and challenges of e-government adoption can be related to technology factors. These include: infrastructure; security; technological/ technical issues; hard/soft gap; digital divide; internet use; and skills related to technology. Hence, it can be concluded that technology is one of the components that needs to be given more attention in this paper.

\section{E-Government Readiness}

In this part of the review, it is time to pay attention to the issue of e-government readiness. As an introduction to the topic, it can be said that government services are provided through a variety of channels including post offices, radio transmission and radar bands, as well as via other public services. Due to the recent advances in technology, most of the government organizations have implemented this technology in their public services. This type of service will henceforth be known as e-government services. In this regard, e-government has several dimensions. One of the main dimensions is that of e-government readiness. To put technology to effective use, a government must be "ready". This is the simple definition of e-government readiness. Joseph (2014) indicates that e-government readiness is the ability of the government to use technology so as to shift traditional services into new services.

A review of literature showed that e-government is vitally important to a country since e-government readiness can help a government to measure its stages of readiness, identify its gaps, and then redesign its government strategy respectively (Joseph, 2014). E-government readiness is not only related to government bodies but is also significant to society, frameworks of government institutions, human resources, interdepartmental relationships, national infrastructure, education as well as any issues that are related to e-government (Ahmed \& Hussein, 2006).

According to Joseph (2014); Mkude \& Wimmer (2013); Almarabeh \& Abuali (2010), the primary reason for e-government failure is a lack of assessment of readiness for e-government, where this lack brings challenges and does not guarantee successful implementation of e-government (Joseph, 2014; Mkude \& Wimmer, 2013). The comparison in Table 1 shows that the majority of barriers and challenges of e-government relate to technology. This result attracted our attention and motivated us to learn more about the technological aspects of e-government readiness.

\section{Technology Readiness of E-Government}

One of the challenges confronting governments that need to be considered is the willingness of people to use technology. Parasuraman (2000) in his research used the term technology readiness". He defined technology readiness as being "people's propensity to embrace and use new technologies for accomplishing goals in home life and at work" (Parasuraman, 2000). From a different point of view, readiness of e-government can be seen as the preparedness of a country to develop and adopt e-government in terms of its technology infrastructure, development of human resources, as well as telecommunication infrastructure. It also denotes the willingness of a government to use advanced technology to improve the lives of its citizens (Mundy \& Musa, 2010). Although studies have been conducted on the significance of technology readiness in organizations, they lack robust 
foundations for empirical analysis (Choucri et al., 2003; Alghamdi et al., 2011). Alghamdi et al. (2011) indicated that there is deficient research connecting technology readiness and implementation of e-government in a country. They recommended that an organizational strategy of ICT and a national program relating to e-government ought to be considered as vital parts of the readiness assessment criteria.

Intake of existing technology and skipping over stages of local technological development is very difficult. The actual technology in use is often limited due to issues such as: the nature of technology; the availability of known technology; and how to make the correct selection from among the available technologies. Less-developed countries never acquire whole technical knowledge. Moreover, technical assistance fails to include technology's implicit steps. Acquiring and learning technology does not depend on buying, producing, selling, and using this technology, but needs an effective search to assess the existing procedures for possible changes (Hamed, 2009).

Regrettably, in spite of the availability of resources and technologies, developing countries face many challenges in developing and implementing e-government projects (Othman \& Razali, 2013). The use of technology is the key to a successful e-government; however, the Internet usage in many developing countries is in its initial stage, which impedes e-government implementation (Kayani et al., 2011).

Developing countries should consider that building telecommunications infrastructure is costly and, in many cases, will need foreign investment in order to develop their infrastructure. Often, developing countries do not have suitable infrastructure for supporting the development of IT. Furthermore, they do not have the ability to invest in the IT field due to poor financial resources and lack of IT knowledge (Hamed, 2009). Information and communication technology can speed the country's development if it is adopted and adapted properly; otherwise, it can frustrate developmental efforts considerably and waste time and scarce resources. A systematic approach of assessing e-readiness forms a correct principle by which to identify and prioritize needs such as technology through proper planning \& organization. Maximizing the benefits of technology needs government support (Colwell \& Hewitt, 2015).

\section{Technological Aspects of E-Government Readiness and the Gap}

Nowadays, the issue of e-government has become a potential imperative at both a national and an international level for the majority of governments. In this situation, according to Azab et al. (2009), e-government is predicated on leveraging the power of technology to deliver services provided by governments. However, e-government is still in an early stage and has not achieved many of the expected outcomes such as cost savings and downsizing, amongst other issues (Azab et al., 2009). Moreover, according to UNDESA (2003) reports, the e-government projects failure rate reached somewhere between $60-80 \%$. Due to the important role of technology, it is necessary to investigate the technological factors influencing e-government readiness especially in the developing countries. In order to find the gap of the study, a comprehensive review of literature was undertaken. It has been found that some technology-related factors have been studied from previous researches. However, there was no comprehensive study which could fulfill all components and factors.

Lau (2003) found that the digital divide can be one of the main factors which influence technological readiness of governments, especially in developing countries. Digital divide means that people who do not have access to the Internet will be unable to benefit from e-government services. In the developing countries, a growing number of individuals are trying to obtain access to the Internet, but there are still large numbers of other people who do not have any internet connection. In this regard, governments in developing countries are trying to improve services to citizens through other channels, since the inability to provide e-government services to all citizens can hold back e-government projects. Lau (2003) also found that security can be identified as another component of technological readiness. It is clear that the use of e-government services without a guarantee of privacy and security is not possible. This is particularly so nowadays due to advances in all fields of human life. In another study, (Belanger \& Carter, 2006) explored the potential effects of the digital divide on e-government by surveying a diverse group of citizens to identify the demographic characteristics that impact upon use of e-government services.

In a further study, Hazlett and Hill (2003) examined the manner in which e-government is being used in the delivery and improvement of services in order to determine actual and potential problems faced by the UK government. Through the study, they found that issues of ICT infrastructure, hardware and software are the main factors of technological readiness which affect e-government services.

Ahmed and Hussein (2006) present a framework model for E-Government Readiness Assessment. They state that there are six necessary key factors to be assessed before launching the e-government program to guarantee the right implementation in the right direction and these are: organizational readiness; governance and leadership readiness; customer readiness; competency readiness; technology readiness and legal readiness. According to 
them, technology readiness includes all necessary technologies to enable the e-government initiative. These comprise applications such as hardware, software, communication and networks infrastructure and Internet penetration respectively.

Azab et al. (2009) developed an e-government appraisal framework encompassing several components such as people, technology, processes, and strategic planning. Technology in this framework comprises information system structure, hardware, as well as technical support and development.

Karunasena et al. (2011) found that the effectiveness of government programs are related to some e-government readiness factors such as financial and technological readiness. From the perspective of technological readiness, ICT infrastructure and security have been identified as key factors which influence e-government. They are working for the improvement of government and public service deliveries. Availability of communication technologies is another main technological factor affecting e-government readiness.

A study by Bakry (2004) introduced the STOPE model in order to provide a base for the development of an international framework related to e-government readiness. The model identified five dimensions (strategy, technology, organization, people and environment). As indicated, one of the components of the model is technology. From the technology perspective, ICT facilities, infrastructure, and support have been identified as e-government readiness factors. Bakry (2004) highlighted that the STOPE model can be useful in decision-making at different stages. Moreover, countries need to consider all dimensions if they are willing to become developed.

A further study Ebrahim and Irani (2005), investigated e-government readiness from a technological perspective. They found five dimensions needed for e-government success. Ebrahim \& Irani (2005) believe that benefits associated with e-government should be considered as factors that influence the implementation process. ICT infrastructure, security, privacy and IT skills are the factors that are related to and associated with e-government readiness from a technological perspective. AISuwaidi \& Rajan (2013) found that technical support, ICT infrastructure and security are the key factors of an e-government implementation.

A study by Kurdi and Randles (2011) examined the technological factors of e-government readiness including the following factors: infrastructure of ICT; infrastructure of network; security infrastructure for data exchange; as well as infrastructure of information system (system, information, and quality of services). In addition, Zaied, Khairalla, \& Al Rashid (2007) explored the e-readiness assessment models so as to assess the readiness of e-government in the State of Kuwait. Three main variables (human skills, infrastructure and connectivity) have been used.

Alghamdi et al. (2011) proposed an e-government framework for assessing the ICT readiness of government agencies in public sector organizations in developing countries. The proposed e-government framework comprises seven dimensions of ICT readiness assessment for government organizations including: e-government organizational ICT strategy; user access; e-government program; ICT architecture; business process and information systems; ICT infrastructure; and human resources. The dimension of ICT infrastructure includes, namely: hardware; software; connectivity; security; and operations.

The factors that previous researchers have focused on are summarized in Table 2. The table illustrates the technology factors that have been found to be influential (significant) on e-government readiness by previous scholars. Moreover, the factors investigated in the present study are presented in the last column. 
Table 2. Comparison between Factors of Technology Readiness of E-government

\begin{tabular}{|c|c|c|c|c|c|c|c|c|c|c|c|}
\hline $\begin{array}{l}\text { Technology Factors of } \\
\text { E-government Readiness }\end{array}$ & 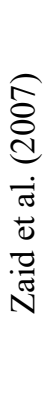 & 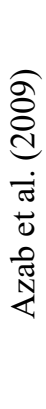 & 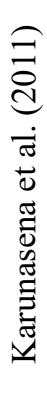 & 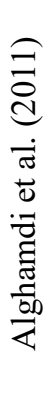 & 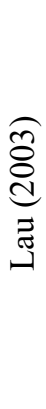 & 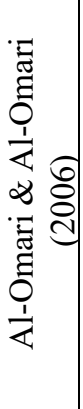 & 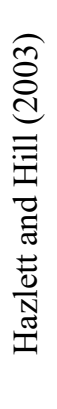 & 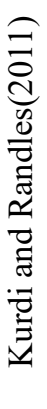 & 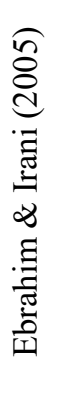 & 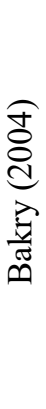 & $\stackrel{\pi}{0}$ \\
\hline \multirow{5}{*}{$\begin{array}{l}\text { Operations } \\
\text { Application } \\
\text { Skills } \\
\text { Internet } \\
\text { Infrastructure of Information } \\
\text { system }\end{array}$} & & & & $\sqrt{ }$ & & & & & & & 1 \\
\hline & & & & & & $\sqrt{ }$ & & & & & 1 \\
\hline & & & & & & & & & $\sqrt{ }$ & & 1 \\
\hline & & & & & & $\sqrt{ }$ & & & & & 1 \\
\hline & & & & & & & & $\sqrt{ }$ & & & 1 \\
\hline \multirow{2}{*}{$\begin{array}{l}\text { Digital Divide } \\
\text { Connectivity }\end{array}$} & & & & & $\sqrt{ }$ & & & & & & 1 \\
\hline & $\sqrt{ }$ & & & $\sqrt{ }$ & & & & & & & 2 \\
\hline \multirow{2}{*}{ Technical support } & & $\sqrt{ }$ & & & & & & & & $\sqrt{ }$ & 2 \\
\hline & & & $\sqrt{ }$ & & & $\sqrt{ }$ & & $\sqrt{ }$ & & & 3 \\
\hline \multirow{2}{*}{$\begin{array}{l}\text { Software } \\
\text { Network Infrastructure }\end{array}$} & & & & $\sqrt{ }$ & & $\sqrt{ }$ & $\sqrt{ }$ & & & & 3 \\
\hline & & & $\sqrt{ }$ & & & $\sqrt{ }$ & & $\sqrt{ }$ & & & 3 \\
\hline Hardware & & $\sqrt{ }$ & & $\sqrt{ }$ & & $\sqrt{ }$ & $\sqrt{ }$ & & & & 4 \\
\hline \multirow{2}{*}{$\begin{array}{l}\text { Security } \\
\text { ICT Infrastructure }\end{array}$} & & & $\sqrt{ }$ & $\sqrt{ }$ & $\sqrt{ }$ & & & $\sqrt{ }$ & $\sqrt{ }$ & & 5 \\
\hline & $\sqrt{ }$ & & $\sqrt{ }$ & & & & $\sqrt{ }$ & $\sqrt{ }$ & $\sqrt{ }$ & $\sqrt{ }$ & 6 \\
\hline
\end{tabular}

It can be observed from Table 2 that there are several technology factors that influence the overall readiness of adopting and implementing e-government. The comparison of these technology factors indicate that factors such as ICT infrastructure, security, hardware, software, network infrastructure and communication are commonly emphasized in all of the studies examined. On the other hand, a few studies have placed an emphasis on operations, application, skills, internet, digital divide, technical support and connectivity. Thus, it can be concluded from the results in Table 2 that readiness of technology factors was not considered in every framework; there are certain factors missing from some studies, but reported in other studies. For example, communication factors, network infrastructure factors and software factors have been identified by three studies as being necessary factors for technology readiness to have a successful implementation of e-government; while these factors are missing from the seven other studies. In addition, the security factor is mentioned by five studies as being a necessary factor of e-government readiness, while this factor is missing from five other studies. Further, digital divide, operations, application, skills, internet and infrastructure of information system are other factors that are mentioned by one study in which they have been identified as technological components of e-government readiness; while these factors are missing from the other nine studies. Hardware is another factor that was mentioned by four studies as being an important factor for e-government implementation, while this factor is missing from six other studies. Moreover, connectivity and technical support are other factors mentioned by two studies as being necessary factors for assessing the readiness of e-government, while these two factors are missing from the remaining eight studies. Finally, the ICT infrastructure factor was mentioned by six studies as being a main component of technological factors related to e-government readiness; while this factor is missing from the other four studies. Thus, the comparison made between the eleven studies in Table 2 shows that there is a lack of identification of the necessary factors to assess technology readiness for e-government implementation.

\section{Conclusion}

The term e-government refers to the utilization of information and communication technology (ICT) by government agencies in order to provide services to citizens. The e-government services enhance government effectiveness and efficiency and change its relationship with the public. E-government readiness studies provide statistics that define the legal, financial, physical, social and technological attributes of infrastructure required by developing countries in order to become a fully networked society. Therefore, it is important to assess 
e-government readiness, including the technological aspects of readiness, in order for the implementation and adoption of e-government to be successful. The goal of this paper is to explore the gaps in knowledge regarding the technological aspects of e-government readiness. This paper has presented a review of the studies for assessing e-government implementation. The review showed that there is a lack of investigation and agreement about the factors that shape the technological aspects of e-government readiness; hence, a clear gap is identified as existing in the current knowledge on the technological aspects of e-government readiness. This work indicates a useful direction which can be taken in future research to investigate the factors related to the technological aspects of e-government readiness.

Hence, future research will be conducted in order to generate a list of the factors shaping the technological aspects of e-government readiness. It is anticipated that this list will be able to assist governments in developing countries to identify and understand the technological aspects that should be considered when assessing the readiness to adopt an e-government project. In addition, the list of technological readiness factors can be used by designers and developers as a guideline for identifying the necessary technological requirements for e-government implementation.

\section{Acknowledgements}

Author would like to thank his family members for their support in the completion of this paper. He also would like to thank the reviewers and editor for their helpful comments.

\section{References}

Abdelkader, A. (2015). A Manifest of Barriers to Successful E-Government: Cases from the Egyptian Programme. International Journal of Business and Social Science, 6(1).

Ahmed, A. M., Mehdi, Q. H., Moreton, R., \& Elmaghraby, A. (2013). E-government services challenges and opportunities for developing countries: The case of Libya. Paper presented at the Second International Conference on Informatics and Applications (ICIA), 133-137. IEEE. http://dx.doi.org/10.1109/ICoIA.2013.6650243

Aisuwaidi, M., \& Rajan, A. (2013). E-Government Failure and Success Factors Rank Model an Extension of Heeks Factor Model. Paper presented at the International Conference on Current Trends in Information Technology (CTIT), 161-165. IEEE. http://dx.doi.org/10.1109/CTIT.2013.6749495

Ahmed, A. O., \& Hussein, A. O. (2006). E-government readiness assessment model. Journal of Computer Science, 2(11), 841-845. Retrieved from http://thescipub.com/PDF/jcssp.2006.841.845.pdf

Alghamdi, I. A., Goodwin, R., \& Rampersad, G. (2011). A suggested e-government framework for assessing organizational e-readiness in developing countries. In International Conference on Informatics Engineering and Information Science. Springer Berlin Heidelberg. http://dx.doi.org/10.1007/978-3-642-25453-6_41

Almarabeh, T., \& AbuAli, A. (2010). A general framework for e-government: definition maturity challenges, opportunities, and success. European Journal of Scientific Research, 39(1), 29-42.

AlNuaimi, M., Shaalan, K., Alnuaimi, M., \& Alnuaimi, K. (2011). Barriers to Electronic Government Citizens' Adoption: A case of Municipal Sector in the Emirate of Abu Dhabi. Paper presented at the Developments in E-systems Engineering (DeSE), 398-403. IEEE. http://dx.doi.org/10.1109/DeSE.2011.65

Alshehri, M., \& Drew, S. (2010). E-government Principles: Implementation, Advantages and Challenges. International Journal of Electronic Business, 9(3), 255-270.

Ashaye, O., \& Irani, Z. (2014). E-government Implementation Benefits, Risks and Barriers in Developing Countries: Evidence from Nigeria. International Journal of Information Technology \& Computer Science (IJITCS), 92-105.

Azab, N. A., Kamel, S., \& Dafoulas, G. (2009). A suggested framework for assessing electronic government readiness in Egypt. Electronic Journal of E-Government, 7(1), 11-28.

Bakry, S. H. (2004). Development of e - government: a STOPE view. International Journal of Network Management, 14(5), 339-350. http://dx.doi.org/10.1002/nem.529

Belanger, F., \& Carter, L. (2006). The Effects of the Digital Divide on E-Government: An Emperical Evaluation. Paper presented at Proceedings of the 39th Annual Hawaii International Conference on System Sciences (HICSS'06). IEEE. http://dx.doi.org/10.1109/HICSS.2006.464

Brown, D. H., \& Thompson, S. (2011). Priorities, Policies and Practice of E-government in A developing Country Context: ICT Infrastructure and Diffusion in Jamaica. European Journal of Information Systems, 
20, 329-342. http://dx.doi.org/10.1057/ejis.2011.3

Choucri, N., Maugis, V., Madnick, S., Siegel, M., Gillet, S., Zhu, H., ... Haghseta, F. (2003). Global e-Readiness-for What? Center for eBusiness at MIT. Retrieved from http://web.mit.edu/polisci/nchoucri/publications/articles/G-7_Choucri_Global_eReadiness_for_What.pdf

Colwell, R., \& Hewitt, M. (2015). Teaching of instrumental music. Routledge.

Conklin, A. (2007). Barriers to Adoption of E-Government. Paper presented at the 40th Hawaii International Conference on Systems Sciences, 1-8. IEEE. http://dx.doi.org/10.1109/HICSS.2007.102

Dada, D. (2006). The Failure of E-government in Developing Countries: A Literature Review. The Electronic Journal on Information Systems in Developing Countries, 26(1), 1-10.

Ebrahim, Z., \& Irani, Z. (2005). E-government Adoption: Architecture and Barriers. Business Process Management Journal, 11(5), 589-611.

Fgee, E. B., \& Alkallas, M. I. (2013). E-government in Libya: Constraints, potentials and implementation. Paper presented at International Conference on Computer Applications Technology (ICCAT), 1-7. IEEE. http://dx.doi.org/10.1109/ICCAT.2013.6521992

Gant, J. P. (2008). Electronic government for developing countries. International Telecommunication Union (ITU), Geneva.

Grant, G., \& Chau, D. (2006). Developing A generic Framework for E-government. Advanced Topics in Global Information Management, 5, 72-101. http://dx.doi.org/10.4018/jgim.2005010101

Hamed, A. (2009). E-commerce and Economic Development in Libya. PhD thesis, University of Wales.

Hazlett, S. A., \& Hill, F. (2003). E-government: the Realities of Using IT to Transform the Public Sector. Managing Service Quality: An International Journal, 13(6), 445-452. http://dx.doi.org/10.1108/09604520310506504

Joseph, S. (2014). Development and Validation of A framework for E-government Readiness Measurement. Durban University of Technology, Durban, South Africa.

Jouzbarkand, M., Khodadadi, M., \& Keyvani, F. S. (2011). Conceptual approach to e-government, targets and barriers facing its. Paper presented at the 5th International Conference on Application of Information and Communication Technologies (AICT), 1-5. IEEE. http://dx.doi.org/10.1109/ICAICT.2011.6110903

Karokola, G., Kowalski, S., \& Yngstrom, L. (2013). Evaluating a Framework for Securing E-Government Services-A Case of Tanzania. Paper presented at the 46th Hawaii International Conference on System Sciences (HICSS), 1792-1801. IEEE. http://dx.doi.org/10.1109/HICSS.2013.208

Karunasena, K., Deng, H., \& Singh, M. (2011). Measuring the public value of e-government: a case study from Sri Lanka. Transforming Government: People, Process and Policy, 5(1), 81-99. http://dx.doi.org/10.1108/17506161111114671

Kayani, M. B., Ul Haq, M. E., Iqbal, M., \& Humayun, H. (2011). Assessing the e-Government Capabilities for Obstacle Identification within Pakistan. Paper presented at the International Conference on Information Society (i-Society), 171-175. IEEE.

Kurdi, R., \& Randles, M. (2011). An Investigation into E-government Information Systems: Analysis and Review of the Literature. Paper presented at Proceedings of the 13th Annual PostGraduate Symposium on The Convergence of Telecommunications, Networking and Broadcasting.

Lam, W. (2005). Barriers to E-government Integration. Journal of Enterprise Information Management, 18(5), 511-530. http://dx.doi.org/10.1108/17410390510623981

Lau, E. (2003). Challenges for E-government Development. Paper presented at the 5th Global Forum on Reinventing Government, 1-18. Mexico City.

Mkude, C. G., \& Wimmer, M. A. (2013). Strategic Framework for Designing E-Government in Developing Countries. Paper presented at International Conference on Electronic Government, 148-162. Springer. http://dx.doi.org/10.1007/978-3-642-40358-3_13

Mollah, M. B., Islam, K. R., \& Islam, S. S. (2012). E-police system for improved e-government services of developing countries. Paper presented at 25th IEEE Canadian Conference on Electrical \& Computer Engineering (CCECE). IEEE. http://dx.doi.org/10.1109/CCECE.2012.6335057 
Monyepao, M. D., \& Weeks, R. V. (2012). Case study: Assessing and Evaluating the Readiness of the ICT Infrastructure to Provide E-government Services at A local Government Level in South Africa. Paper presented in the Proceedings of PICMET '12: Technology Management for Emerging Technologies (PICMET). 2778 - 2784. IEEE.

Mouzakitis, S., \& Askounis, D. (2010). A knowledge-based Framework for Measuring Organizational Readiness for The Adoption of B2B Integration Systems. Information Systems Management, 27(3), 253-266. http://dx.doi.org/10.1080/10580530.2010.493842

Mundy, D., \& Musa, B. (2010). Towards A framework for E-government Development in Nigeria. Electronic Journal of E-Government, 8(2), 148-161.

Ndou, V. (2004). E-government for Developing Countries: Opportunities and Challenges. The Electronic Journal of Information Systems in Developing Countries, 18.

Novakouski, M., \& Lewis, G. A. (2012). Interoperability in the e-Government Context. Dtic Document. Carnegie-Mellon Univ Pittsburgh Pa Software Engineering Inst.

Odat, A. M. (2012). E-Government in developing countries: Framework of challenges and opportunities. Paper presented at International Conference for the Internet Technology And Secured Transactions, 578-582. IEEE.

OECD. (2008). Future of E-government-Agenda 2020. OECD E-Leaders Conference 2008.

Othman, M., \& Razali, R. (2013). Key contributing factors towards successful Electronic Government systems interoperability. Paper presented at International Conference on Research and Innovation in Information Systems (ICRIIS), 302-307. IEEE. http://dx.doi.org/10.1109/ICRIIS.2013.6716726

Parasuraman, A. (2000). Technology Readiness Index (TRI) a multiple-item scale to measure readiness to embrace new technologies. Journal of service research, 2(4), 307-320. http://dx.doi.org/10.1177/109467050024001

Qaisar, N., \& Khan, H. G. A. (2010). E-Government challenges in public sector: A case study of Pakistan. International Journal of Computer Science Issues (IJCSI), 7(5), 310-317.

Solli, S. H. (2010). Analytical framework for e-government interoperability. Paper presented at the eChallenges e-2010 Conference, 1-9. IEEE.

UNDESA. (2003). E-government at the Crossroads. World Public Sector Report 2003. United Nations Department of Economic and Social Affairs. United Nations, New York.

Wang, H., \& Hou, J. (2010). Perspectives, Skills and Challenges for Developing A successful E-government. Paper presented at International Conference on Advanced Management Science (ICAMS), 3, 242-245. IEEE. http://dx.doi.org/10.1109/ICAMS.2010.5553248

Zaied, A. N. H., Khairalla, F. A., \& Al Rashid, W. (2007). Assessing e-readiness in the Arab countries: Perceptions towards ICT environment in public organisations in the State of Kuwait. Electronic Journal of E-government, 5(1), 77-86.

Zhang, N., \& Hou, X. (2011). Government Process Management under electronic government and its application. Paper presented at International Conference on E-Business and E-Government (ICEE), 1-4. IEEE. http://dx.doi.org/10.1109/ICEBEG.2011.5881951

Ziaie, P. (2013). Challenges and issues of ICT Industry in Developing Countries Based on A case Study of the Barriers and the Potential Solutions for ICT Deployment in Iran. Paper presented at the International Conference on Computer Applications Technology (ICCAT), 1-6. IEEE. http://dx.doi.org/ 10.1109/ICCAT.2013.6521973

\section{Copyrights}

Copyright for this article is retained by the author(s), with first publication rights granted to the journal.

This is an open-access article distributed under the terms and conditions of the Creative Commons Attribution license (http://creativecommons.org/licenses/by/4.0/). 